\title{
Espejo de enemigos de Marcelo Rioseco
}

Santiago, Chile: Uqbar Editores, 2010, 88 páginas.

\author{
ISMAel GaVilán MuÑoz \\ Universidad Viña del Mar. Viña del Mar, Chile \\ Fundación Pablo Neruda \\ igavilan@uvm.cl
}

uando se menciona la palabra tradición, una de las primeras imágenes que se nos viene a la mente es de lo inmóvil y anquilosado, lo carente de imaginación empotrado en repetitivas prácticas autoritarias y que adolece de argumentos racionales para justificar su propia condición que no sea la imagen que ella misma articula de sí en un gesto tautológico y opaco. Al menos esa es la idea que sotto voce puede circular como opinión en diversos medios y contextos.

Pero cuando abordamos la literatura y a la poesía en específico, referirse o dar cuenta de la palabra tradición es, al menos, redundante, incluso cuando la legítima pretensión de toda ruptura instaura un perpetum mobile de gestos, actitudes y maneras que vuelve la búsqueda de lo "nuevo" y "original" en un recurso de actualización permanente, haciendo guiños cómplices a lo que aparentemente desea superar o dejar abandonado a la vera del camino.

Hoy por hoy, ya es un lugar común hablar o referirse a los "clásicos de la modernidad" o a la "tradición moderna" en un delicioso oxímoron que, más allá de develar una excentricidad retórica, muestra la aprehensión y versatilidad que el término posee en un vitalismo duro de apaciguar. Y no deja de ser interesante advertir cómo la "tradición moderna" -con nombres tan representativos como Joyce, Kafka o Beckett- es tal vez una relectura, un comentario y una apropiación sanamente contradictoria en su manera, de la así también llamada "tradición clásica" y que vuelve a la herencia grecolatina en sus aristas casi infinitas, uno de sus puntos de apoyo ineludibles. En la modernidad, la "tradición clásica" se actualiza y se recrea. Como ha manifestado Gilbert Highet, ni el griego ni el latín son lenguas muertas, puesto que, directamente o a través de las traducciones, dicen todavía su mensaje, deleitan, inquietan, conmueven y apasionan. Sin duda que la "tradición clásica” ha sido un estímulo y un desafío para generaciones enteras de escri- 
tores modernos y contemporáneos. En la tarea de emulación, superación y recreación ha consistido, justamente, la grandeza de innumerables obras del pasado y de nuestros días.

En el contexto de la poesía escrita en nuestro país, la "tradición clásica" ha ocupado un lugar subsidiario, pero no menos relevante, opacado sin duda por la preeminencia de otras tradiciones y aventuras de la imaginación y el lenguaje. Pero aun así, hay una estela fluctuante, densa y, ante todo, persistente por hacer de aquella tradición referencia primordial para los ejercicios imaginativos de varios poetas nacionales. En un arco que va desde principios del siglo XX con Egidio Poblete, el magistral traductor de La Eneida, hasta la presencia clásica latina en diversos poemas de autores tan disímiles como Gonzalo Rojas, Alberto Rubio y Armando Uribe como, asimismo, en libros que se han vuelto verdaderos puntos de referencia como lo es Mecenas de Antonio Cussen, hasta llegar a las traducciones actuales de Horacio y Catulo efectuadas por Leonardo Sanhueza, Juan Cristóbal Romero y Oscar Velásquez, es posible bosquejar no sólo un simple marco de referencia o un mapa de sutiles gustos extemporáneos, sino más bien puede advertirse una interesante motivación para dar cuenta de un modo de entender o abordar la escritura, una escritura traspasada, en lo fundamental y sin temor a agregar otras características, por un no menor rigor formal, una predilección por un lenguaje directo, cuidadoso de su adjetivación, cierto laconismo expresivo y la importancia de una actitud meditativa que no se desdiga de su propia articulación retórica.

Es bajo estas coordenadas, a nuestro parecer, donde es posible situar la publicación en 2010 de Espejo de enemigos de Marcelo Rioseco, un poeta del que no teníamos noticia desde su celebrado Ludovicos o la aristocracia del universo que, a mediados de la década del 90, fue sin duda uno de los libros más relevantes para dar cuenta de esa sensibilidad pletórica de imágenes y de indagación lingüística que sería uno de los pilares de la así denominada generación de los 90. De vuelta de siglo, el retorno de Rioseco a los avatares de la publicación no viene a ser precisamente una sorpresa -pues ha estado entregado a menesteres tan complementarios de la escritura poética como puede ser la traducción y el de fungir de antologador-, sino más bien es una especie de asunción crítica de ese primer impulso verbal que significó $L u$ dovicos. Ciertamente es relevante constatar no tanto una ruptura en el tono asumido por un ejercicio escritural dispuesto en poco más de una década, sino que es dable rastrear la decantación de una poética que viene desde una eventual aventura épica en las fronteras de la imaginación y el vuelo, hacia la indagación crítica de su entorno bajo el ropaje fructífero y diverso de esa 
tradición clásica de la que, al fin de cuentas, este libro es tributario.

Pero una salvedad de esta relación de la poesía de Rioseco con la "tradición clásica" es que no viene dada por un mero ejercicio de mímesis o una traducción en el sentido sancionado por el uso. Para nada: nos encontramos en presencia de un libro que recoge libremente a esa tradición, se la apropia y la vuelca en una serie de poemas de plena libertad compositiva, donde es primordial una relectura vigilante y crítica de ese rico repertorio representado por la poesía latina. En esto Rioseco, a semejanza de Ezra Pound, Robert Graves o el Ricardo Reis de Pessoa, está menos interesado en la exactitud filológica e histórica de sus referentes que en establecer un escenario flexible para hacer "hablar" a una serie de personajes que parafrasean temas, motivos, símbolos y figuras que se han desplazado desde su virtual encasillamiento libresco hacia una reactualización vivaz y crítica que, el poeta chileno, asume con inteligencia y desfachatez.

De esto resulta un libro coral de voces entrecruzadas donde los diversos personae que lo componen, asumen un discurso que va desde la más ácida crítica al poder en sus diversas formas -ya políticas, ya acerca del establishment de la cosa poética-, hasta la declaración desinhibida de la entrega total a una vida artística, pasando por una verdadera apología del placer y el sexo, maledicencias varias y una serie de agudas y pertinentes reflexiones en torno al sentido y sinsentido de la poesía y el rol del poeta en una, a veces, más real que imaginaria sociedad plagada de cortesanos, apariencias concertadas y damas de honestidad dudosa. Bajo los nombres ficticios de resonancia latina que traen un dejo de exotismo culterano a los poemas del libro, vemos circular en él a Suetonio, a Máximo Valerio, a Quinto Fabio, a Marco Marcelo y a varios otros personajes que, en su evocadora nominación latina, marcan una aparente distancia con el lector, sobre todo si éste cae en la tentación recurrente de buscar una pretendida exactitud histórica en estos nombres. Aquello, de todas formas, le guiará a un callejón sin salida, pues más que esa pretensión de veracidad, lo que la poesía de Rioseco busca es la expresión plural, por medio de todas estas voces, de un temple o más estrictamente de una disposición hacia el poema en tanto objeto artístico que logre dar cuenta de esa peculiar práctica que la distancia y la cercanía nominan como parodia, es decir, como un simulacro estético que, gracias a su gratuidad expositiva, no renuncia a la evocación, sino que se sirve de ella para entregarnos un diagnóstico feroz de esa dialéctica entre lo que es real y la apariencia de eso que asumimos como real.

De esta forma, en la poesía de Rioseco es posible vislumbrar una despersonalización altamente productiva a la hora de hacer del poema, un objeto 
ya no de la confesión personal o del juicio abstracto teñido de moralismo denunciante, sino un objeto donde el lenguaje, pretendiendo una virtual transparencia -aquí los juegos verbales e imaginarios de Ludovicos están a distancia sideral, no así, pienso, su pretensión de escenificación de la experiencia- se queda en eso: algo virtual que articula su ganancia de significado cuando nos invita a recrear y leer a contrapelo las figuras entre serias y risibles que posibilitan la puesta en escena de sus convenciones retóricas. Porque ciertamente, aquí, la parodia no se sirve de un lenguaje hiperbólico o de degradación, sino más bien, con una ironía de sabia factura, los poemas de Rioseco en ningún momento bajan el tono de su lenguaje elevado que, curiosamente, no busca la pomposidad de la expresión barroca, sino la llaneza aclaradora como de la engañosa superficie de un lago cristalino que, besado por la luz del sol veraniego, esconde, bajo su efigie de serenidad, la densa contradicción de sus giros verbales a modo de una conversación inteligente de la que hay que oír, entre líneas, el trabajo de desmantelación del sentido.

Por todo esto, la poesía de Rioseco, en su aparente llaneza, no es accesible a la inmediatez de una recepción plagada de prejuicios: ver en ella mero "culteranismo escapista" o lo que es peor, cierta "pedantería" que no oculta su predilección por sus fuentes clásicas es, qué duda cabe, errar la mirada de tan interesante libro en lo que va de la poesía chilena contemporánea. ¿Un esfuerzo en solitario acaso? Para nada y no sólo por la red de referencias que mencionábamos al principio en tanto la existencia de una "atmósfera" en nuestra poesía más actual que respira la "tradición clásica” -cosa cierta aquélla-, sino también porque la poesía de Rioseco es dable hacerla entrar en diálogo con aquellos esfuerzos que hacen, de la lectura de la tradición, una fecunda fuente de referencias críticas que no de mera comodidad libresca para zaherir y cuestionar el campo literario del cual surge. El poema como palimpsesto, pero no para recrearse a sí mismo en los deleites opacos de la erudición sin arraigo, búsqueda más bien de ese mismo arraigo en tanto exploración de una memoria asediada por la turbulencia amnésica de la hora presente. 